Charlotte Jørgensen

Lektor, Afdeling for Retorik, Institut for Medier, Erkendelse og Formidling, Københavns Universitet

\title{
Snyd med sproghandlinger: Et retorisk casestudie fra den danske politiske debat
}

\section{Sammendrag}

Casen i denne artikel er fra det danske kommunalvalg i 2005 hvor den fremtrcedende politiker Ritt Bjerregaard blev overborgmester for København. Den er kendt som 'sagen om de billige boliger', der indgår i rækken af sager om brudte valgløfter i den politiske debat i Danmark. Sagen tages op som et eksempel på en mere generel debatadfcerd hvor der forekommer misbrug i form af 'snyd med sproghandlinger'. I casen er det snyd i forbindelse med løftet som sproghandling der er i fokus, men det videre sigte med casestudiet er at liegge op til studier af adferd der også involverer andre sproghandlinger, og som strider med god deliberativ retorik.

Sagen om de billige boliger belyses i artiklen ud fra næranalyse af to tekster. I analysen appliceres begreber fra talehandlingsteorien, som i den efterfølgende diskussion og vurdering kombineres med det retoriske redelighedskriterium. Artiklen er således også et forsøg på at illustrere hvordan talehandlingsteorien kan inddrages i retorisk kritik.

\section{Indledning}

'Man har et standpunkt til man tager et nyt' lød en opsigtsvækkende udtalelse fra den tidligere danske statsminister Jens Otto Krag. Han sagde det i 1966 da han dannede sin socialdemokratiske regering med venstrefløjspartiet SF som støtte, det såkaldte "Røde Kabinet”, selv om han inden valget havde afvist denne mulighed. ${ }^{1}$ Talemåden er siden da blevet en topos i dansk politisk debat, som bruges hyppigt når emnet nærmer sig løftebrud, især i forbindelse med valgkampe.

Casen i denne artikel indskriver sig i rækken af sager om brudte valgløfter i den senere tids danske politiske debat, en udvikling som foreløbig er kulmineret med de mange anklager om løftebrud efter folketingsvalget i efteråret 2011. Den er kendt som sagen om "de billige boliger", der vakte megen furore i de danske medier og stadig står levende i den danske vælgerbefolknings erindring. Sagen drejer sig om den fremtrædende socialdemokratiske politiker Ritt Bjerregaard, der i valgkampen til posten som Københavns overborgmester gjorde en plan for opførelsen af boliger som almindelige borgere kunne betale, til sin

\footnotetext{
${ }^{1}$ http://da.wikipedia.org/wiki/Jens_Otto_Krag, hentet 14. november 2011.
} 
mærkesag. Hun vandt valget og var overborgmester i 2006-2009, men den storstilede byggeplan kuldsejlede.

Jeg behandler casen som et eksempel på en argumentationsadfærd inden for politisk debat som jeg har valgt at kalde 'snyd med sproghandlinger'. ${ }^{2}$ Med lanceringen af dette udtryk sigter jeg til forskellige brud på god retorik hvor politikere kommunikerer manipulerende mht. den sproghandling de udfører. Den typiske adfærd består i at man direkte benægter den sproghandling man er i gang med eller har udført, at man foregiver det indirekte, eller at man siger eller lader som om man udfører en anden sproghandling end den man udfører. Vi oplever fx 'snyd med sproghandlingen' i situationer hvor debattører fremfører at det de siger, sandelig ikke er en trussel når det i den givne situation klart er hvad der tale om, eller når politikere midt i en debatterende kommunikationssituation bedyrer at de ikke er ude på at overtale nogen, kun at informere. Det er også snyd med sproghandlingen når politikere og andre samfundsdebattører giver sig til at undskylde uden at gøre det rigtigt eller af andre grunde end de foregiver. ${ }^{3}$ Som skitseret med disse eksempler refererer jeg med udtrykket 'snyd med sproghandlinger' til et sammensat mønster af debatadfærd der omfatter forskellige typer illokutionære og perlokutionære sproghandlinger, ${ }^{4}$ og som er kendetegnet ved at debattøren kommunikerer på en måde der er vildledende mht. den pågældende sproghandling.

Mht. betegnelsen 'snyd' vælger jeg dette ord for at angive at den debatadfærd jeg sigter til, kan dække mere eller mindre bevidste og bedrageriske eksempler på misbrug. Den elastiske betydning af 'snyd' har den fordel at ordet kan rumme kritikerens graduerede vurderinger, der i lyset af den konkrete situation befinder sig på en skala spændende fra små forseelser - fx ufrivillige eller små fejltrin uden væsentlig betydning i situationen (den slags snyd man også kunne kalde 'fusk') - til store overgreb, fx sådanne som er bevidst bedrageriske og grove tilsidesættelser af normer for legitim sproghandlen og god deliberativ retorik (den slags snyd man også kunne kalde 'svindel'). ${ }^{5}$

I sagen om de billige boliger drejer det sig nærmere betegnet om snyd i forbindelse med sproghandlingen at love, som er sproghandlingsteoriens skoleeksempel på den illokutionære sproghandling i traditionen fra Austin (1975) og hans arvtager Searle (1969). ${ }^{6}$ I

\footnotetext{
${ }^{2}$ Denne artikel er en udvidet bearbejdelse af et paper ved argumentationskonferencen i Amsterdam i 2010. Her brugte jeg som engelsk oversættelse udtrykket "fudging speech acts” (Jørgensen 2011).

${ }^{3}$ Som et dansk eksempel på dette kan nævnes den tidligere statsminister Anders Fogh Rasmussen der blev beskyldt for at udstede en officiel undskyldning for at fremme egne politiske anliggender, jf. Villadsen (2008).

${ }^{4}$ Forskellen illokutionær-perlokutionær handling kan fx illustreres med verberne true-skræmme og argumentereovertale/overbevise.

${ }^{5}$ Walton er inden for argumentationsteorien repræsentant for et tilsvarende gradueringsprincip for vurderingen i den konkrete sammenhæng af de argumenttyper der er relateret til de traditionelle fejlslutninger ( jf. Walton 1995, s. 250ff.)

${ }^{6}$ Danske introduktioner og korte fremstillinger om talehandlingsteorien kan bl.a. læses i Andersen 1989, Hansen og Heltoft 2011 (bind I kap. 1, I B, s. 43ff.), Henriksen 2001 (s. 12-21), Husted 1982, Wille 2007 (s. 195-206). Om forholdet mellem retorik og læren om talehandlinger: Jørgensen og Kock 2009.

På dansk bruges både termen 'sproghandling' og 'talehandling' for det engelske speech act. I denne artikel benyttes fortrinsvis den første term.
} 
tråd med den deliberative genres fremtidsorientering spiller løfter en væsentlig rolle i politisk retorik, specielt i valgkampe, hvor der er en hårfin grænse mellem at advokere for fremtidige løsninger på mærkesager i partiernes valgprogram og at love at gennemføre en politisk løsning eller undlade at gøre det. Tendensen til at skride fra det ene til det andet har været betegnende for udviklingen af den danske politiske debat i en ti års periode med udbredelsen af den såkaldte 'kontraktpolitik' indført af den tidligere statsminister Anders Fogh Rasmussen. Kontraktpolitikken - dvs. udmeldingen af en liste med punkter som et parti lover at overholde ubetinget frem til næste valg hvis den kommer i regering - kan, dens øvrige fordele og ulemper ufortalt, ses som et forsøg på at undgå valgflesk og gyldne valgløfter og den deraf følgende tillidskløft mellem vælgerbefolkningen og politikerne. Når et valgløfte ikke holdes efter valget, er vælgerne nemlig tilbøjelige til at tolke løftet som et bedragerisk trick som udelukkende blev givet for at skaffe sig deres stemmer og sikre sig magten for enhver pris.

Men hvornår er der så tale om at politikeren afgiver et egentligt løfte, og hvordan skal man som kritiker i et normativt retorisk perspektiv forholde sig til politikeres adfærd mht. løfter og løftebrud? Det er sådanne spørgsmål som denne artikel tager op til overvejelse med casestudiet som eksempel på hvordan man kan analysere og vurdere politisk retorik mht. snyd med sproghandlinger. Sagen om de billige boliger belyses i det følgende med fokus på to tekster. For at indkredse arten og omfanget af Ritt Bjerregaards snyd med sproghandlingen appliceres begreber fra sproghandlingslæren på teksterne og kombineres i den afrundende diskussion med vurderingskriteriet redelighed (Jørgensen og Onsberg 2008). Som optakt til den nærmere analyse af sproghandlingerne i de to tekster følger først en præsentation af sagen og den sammenhæng teksterne indgik i.

\section{Teksternes kommunikationssituation}

Ritt Bjerregaard (f. 1941) er kendt som en af de mest indflydelsesrige socialdemokrater i Danmark. Hun har været medlem af Folketinget det meste af perioden 1971-2005 og bestredet betydningsfulde politiske hverv, bl.a. som undervisningsminister, socialminister, miljøkommissær i EU og fødevareminister, inden hun stillede op til overborgmesterposten for København. Gennem hele sin politiske karriere har Ritt Bjerregaard markeret sig som en kontroversiel politiker der har givet anledning til en række skandalesager i medierne, men som har demonstreret en forbløffende evne til politisk overlevelse på trods af de tilbageslag hun har lidt både inden for partiet og i offentlighedens øjne. Til hendes omdømme hos befolkningen hører et ry for arrogance, følelseskulde og god smag med hang til ekstravagance. Hendes dagsordenssættende gennemslagskraft har været betydelig. Hun betragtes som en på én gang beundringsværdig modig og besværlig politiker der siger hvad hun mener, og ikke viger tilbage for at tale partitoppen midt imod. Hun er ikke den der lader sig kommandere af sine overordnede når tingene spidser til, men er selv blevet beskyldt for at optræde diktatorisk over for kolleger og underordnede. Hun fremtræder som en helhjertet feminist med 'hår på brystet'. I relation til de traditionelle retoriske etos-dimensioner (Aristoteles 2.I.5-7, McCroskey 1997) efterlades man med indtrykket af en politiker der står stærkt mht. kompetencedimensionen - intelligent og vidende om de sager hun tager op og 
forfølger med stor integritet, men som i visse henseender udviser en påfaldende svigtende dømmekraft. Da Ritt Bjerregaard gik af som overborgmester, blev det fremhævet som del af hendes skudsmål at hun havde været bedre til at positionere sig selv i centrum af dansk politik end til at efterlade sig politiske resultater. ${ }^{7}$

I valgkampen til kommunalvalget d. 15. november 2005, hvor Ritt Bjerregaard var socialdemokraternes kandidat som overborgmester for København, fremlagde hun sin plan for at afhjælpe hovedstadens hastigt stigende boligproblem som gjorde det vanskeligt for mange at bosætte sig i København. Det var omkring dette tidspunkt huspriserne for alvor eksploderede, inden finanskrisen et par år senere satte ind. Planen gik ud på at skaffe boliger i København som folk med almindelige indkomster, fx skolelærere, sygeplejersker, politifolk og unge familier, havde råd til at flytte ind i. Hun gjorde det under sloganet: "5.000 boliger til 5.000 kr. inden for fem år”.

Valget til Københavns Borgerrepræsentation blev en sejr for Socialdemokraterne, og Ritt Bjerregaard tiltrådte som overborgmester i januar 2006 med hele 60.000 personlige stemmer. I lyset af hele sagens forløb og ud fra mediernes interesse for sagen er det nærliggende at antage at planen om de billige boliger var en væsentlig medvirkende grund til valgsejren. $^{8}$

Mht. forslagets relevans kan det dårligt betvivles at det forholdt sig til et reelt problem. Boligsituationen udgjorde - med Bitzers terminologi - et klart exigence, dvs. et presserende problem som mange københavnere måtte erkende som sådant og føle et oplagt behov for at få løst, også de der ikke selv havde problemet inde på livet, men bekymrede sig om konsekvenserne for byen mht. variationen af indbyggere. Vi kan også antage at planen blev betragtet som fitting response af store dele af borgerne, der som publikum deltog i rollen som mediators of change, selvfølgelig især af dem som det forlød om at de havde stemt på Ritt Bjerregaard på grund af de billige boliger. Det springende punkt ved 'den retoriske situation' vedrører i dette tilfælde constraits, de 'tvingende omstændigheder', de positive såvel som, og her især, de negative (Bitzer 1968). Og forudsigeligt nok var det også på dette punkt Ritt Bjerregaards modkandidater i valgkampen satte ind ved at bestride hele projektets gennemførlighed og slå på de forhold der gjorde det urealisabelt.

Efter valget blev implementeringen af det som man under valgkampen havde opfattet som et valgløfte, nøje overvåget og dækket i medierne. Det stod hurtigt klart at byggeplanen trak i langdrag. Debatten blussede kraftigt op hen mod sommeren 2007 efter at projektet var stødt ind i forskellige hindringer, først og fremmest den borgerlige regerings afslag på ansøgningen om at kommunen til formålet skulle kunne sælge byggegrunde til en værdi under markedsprisen. På det tidspunkt var der blevet opført 12 billige boliger. Ritt Bjerregaard stillede op til et avisinterview, hvor hun henvendte sig til offentligheden om sagen og forklarede vanskelighederne som betød at projektet ikke kunne gennemføres på fem år (Weiss

\footnotetext{
${ }^{7}$ Birgitte Possing 2003 http://www.kvinfo.dk/side/597/bio/149/, http://da.wikipedia.org/wiki/Ritt_Bjerregaard samt Davidsen-Nielsen 2009b.

${ }^{8}$ I en senere avisoverskrift blev planen fx omtalt som ”det store valgtema” (Kjær \& Jessen 2007).
} 
2007). Hun erklærede nu at hun aldrig havde lovet det som sloganet handlede om, kun at hun ville arbejde for det hvis hun blev valgt. At vælgerne i København havde en anden opfattelse fremgår af en meningsmåling dagen efter for Berlingske Tidende. Et af spørgsmålene lød: "Mener du, at Ritt Bjerregaard afgav et valgløfte om at bygge 5.000 boliger til 5.000 kr. på fem år i København?” Hertil svarede $83 \%$ ja. Af dem der stemte på Socialdemokraterne i 2005, mente $77 \%$ at det var et løfte (Gallup 2007, s. 2). Af undersøgelsen fremgik det også at $62 \%$ af vælgerne mente at sagen svækkede Ritt Bjerregaards troværdighed, mens 31\% ikke tillagde den betydning for troværdigheden. Blandt de socialdemokratiske vælgere var procenterne henholdsvis 49 og 42 (Ibid., s. 5).

Den opsigtsvækkende benægtelse afstedkom en voldsom debat med indlæg af borgere som følte sig bedraget, hoverende politikere fra andre partier, andre socialdemokrater og borgmestre som i mere eller mindre diplomatiske vendinger over for Ritt Bjerregaaard tog afstand fra benægtelsen af gyldne valgløfter, og endelig fra nogle få støtter og medarbejdere fra Rådhuset på tilbagetog.

Efter denne begivenhed stod det efterhånden mere og mere klart at hele projektet næppe nogensinde ville blive ført ud i livet. I december 2008, hvor der stadig kun var opført 12 billige boliger, indrømmede Ritt Bjerregaard at heller ikke prisen ville kunne holdes på de 5.000 kr. (Nielsen \& Knudsen 2008). I 2009, da tiden for den næste valgkamp nærmede sig, meddelte Ritt Bjerregaard at hun ikke stillede op til genvalg som overborgmester. Som hovedgrund anførte hun den uhensigtsmæssige administrationsstruktur på Københavns rådhus - sagen om de billige boliger havde ingen betydning for beslutningen, sagde hun. Ifølge en meningsmåling sidenhen under valgkampen mente $38 \%$ af københavnerne om Ritt Bjerregaards indsats som overborgmester at hun havde klaret opgaven "godt eller mindre godt”, mens 39\% mente hun havde klaret den "dårligt eller meget dårligt” (Davidsen-Nielsen 2009a).

\section{Tekst 1: Løftet før valget}

Det spørgsmål der melder sig umiddelbart, er om Ritt Bjerregaard så faktisk aflagde et løfte i første omgang? Svaret er et utvetydigt ja. Det fremgår klart af nedenstående uddrag fra den tekst som jeg her refererer til og nærlæser mht. sproghandlingen i de passager der mest direkte vedrører spørgsmålet. Teksten har som sagt Ritt Bjerregaard selv som afsender og blev bragt i Information, som gennem en ugentlig serie med overskriften "Borgmesterduellen” bragte de fire kandidaters valgoplæg (Bjerregaard 2005). Teksten kan læses i sin helhed på http://www.information.dk/114350 (hentet 24.11.2011) og i lærebogen Praktisk argumentation (Jørgensen og Onsberg 2008, s. 25-26). Selv om man vil kunne finde flere andre tekster fra valgkampen hvor Ritt Bjerregaard fremlagde sin plan om de billige boliger, holder jeg mig kun til denne tekst. Det sker ud fra betragtningen at er der blot i denne ene 
sammenhæng i valgkampen afgivet et løfte, er andre tekster af tilsvarende art i princippet irrelevante. ${ }^{9}$ De relevante passager fra tekst 1 for sproghandlingsanalysen gengives her.

Uddrag fra Ritt Bjerregaards valgoplæg i Information, d. 27. oktober 2005 (kursivering tilføjet):

\section{København må ikke blive en velhaverghetto}

Det er muligt, som jeg har lovet, at bygge 5.000 boliger til 5.000 kr. om måneden inden for fem år

[...]

Derfor har jeg bundet mig til at bygge 5.000 boliger om måneden inden for fem år. Men siden jeg først foreslog det, har politikere fra Venstre og SF (!) konkurreret om at skyde mit forslag ned.

$[\ldots]$

Jeg accepterer simpelthen ikke påstanden om, at det ikke kan lade sig gøre at sænke omkostningerne for byggeri i København.

[...]

Med de stordriftsfordele, der bliver ved et meget større byggeri, er jeg stensikker på, at det kan lade sig gøre. [...] Med en vilje til politisk styring af boligbyggeriet i København, så kan vi naturligvis bygge flere, billige boliger.

[...]

Forslaget om 5.000 boliger til 5.000 kroner er naturligvis et opgør med vanetænkning i byggebranchen og i boligpolitikken i København. Og derfor møder forslaget modstand. Men naturligvis kan det lade sig gøre, og naturligvis bliver det dejlige boliger. Mon ikke, når valgkampen er slut, at en hel del af de politikere, der nu kritiserer ideen, vil være med til at gennemføre den?

Som det fremgår sort på hvidt, bruger Ritt Bjerregaard selv verbet at love. Som det er hovedreglen for almindelig sprogbrug, udtrykker hun sig ikke i overensstemmelse med performativformlen (bestående af den såkaldte illokutioncere komponent + propositionen, jf. Hansen og Heltoft 2011, Kap 1, § 9.1): ”Jeg lover dig/jer hermed at...”. I stedet udtales sproghandlingen med en omskrivning til ledsætningen der henviser til fortiden (som jeg har lovet), men i sammenhængen er det klart at helsætningen i manchetten tæller som et løfte. Hun bruger ligeledes den forstærkende formulering at hun har bundet sig til at udføre planen. Lige efter følger sætningen med ord afledt af verbet at 'foreslå', som jo i sig selv er en svagere, dvs. mindre forpligtende sproghandling end at 'love'. I sammenhængen ophæver sætningen imidlertid ikke det forhold at hun i teksten afgiver et løfte. Meningen må forstås sådan at hun tidligere har udkastet ideen og foreslået en plan for den, som hun nu omtaler og

\footnotetext{
${ }^{9}$ Sagen ville naturligvis forholde sig anderledes hvis Ritt Bjerregaard havde trukket løftet tilbage inden valget i en sammenhæng hvor det med rimelighed kunne forventes at blive gjort bekendt for borgerne; men det var der, så vidt jeg ved, ikke tale om.
} 
vedstår som et løfte. I de næste citater tager Ritt Bjerregaard spørgsmålet om planens gennemførlighed op. Hun forholder sig altså her til en af de grundlæggende topoi for politisk debat (Er forslaget gennemførligt?), som hun som forslagsstiller har til opgave at argumentere for. Også fremstillingen er her meget insisterende: det konstateres uforbeholdent at opførelsen af de 5.000 boliger til 5.000 kr. på fem år (løftets propositionelle indhold) kan lade sig gøre, jf. de stærke optoninger "simpelthen”, "stensikker" og "naturligvis".

\section{Tekst 2: Om løftet efter valget}

Da Ritt Bjerregaard halvandet års tid efter tiltrædelsen som overborgmester besluttede at offentliggøre at byggeplanen måtte revideres, var det nærliggende, som det blev fremført af en politisk kommentator, at se udmeldingen som et forsøg på at få overstået den uundgåeligt stærkt negative kritik i god tid inden det næste kommunevalg (Qvortrup 2007). Hun henvendte sig denne gang til offentligheden i et interview, som blev bragt i avisen Berlingske Tidende (Weiss 2007). I interviewet udtaler Ritt Bjerregaard sig om en række forskellige problemer hun kæmper med på rådhuset. Det første er sagen om de billige boliger; hun har et par dage inden modtaget regeringens afslag på ansøgningen om indirekte økonomisk støtte gennem rabat ved salget af kommunens grunde til byggeriet. (Afsnittet ”Jeg laver ikke kontraktpolitik” i tekstudskriften er også gengivet i Jørgensen og Onsberg 2008, s. 119)

Uddrag fra interview af Jakob Weiss med Ritt Bjerregaard i Berlingske Tidende, d. 10. juli 2007 (kursivering tilføjet):

\section{"Jeg har aldrig lovet $\mathbf{5 . 0 0 0}$ billige boliger på fem år”}

[...] regeringens afvisning [...] kom ikke som den store overraskelse for overborgmesteren, der reelt har opgivet at leve op til sit valgløfte [...]

Men, understreger Ritt Bjerregaard, hun har aldrig lovet københavnerne at der ville komme 5.000 boliger på fem år - hun har lovet, at hun vil arbejde for, at der kom 5.000 billige boliger i løbet af fem år. Og selv om man nok skal have været i politik i en menneskealder for at se den store forskel, så er det ikke desto mindre afgørende, mener Ritt Bjerregaard.

\section{"Jeg laver ikke kontraktpolitik"}

”Det kan godt lade sig gøre at bygge 5.000 billige boliger - men ikke på fem år. Det kommer måske til at tage syv, otte, ni eller ti år, jeg kan ikke sige det, men jeg skal ærligt indrømme, at det er kommet bag på mig, at jeg skal igennem så mange vanskeligheder bl.a. med en regering, der mildest talt ikke er hjælpsom. Og når det er sagt, så har jeg aldrig lovet, at de billige boliger ville stå klar efter fem år. Det er et vigtigt princip for mig, at jeg ikke laver kontraktpolitik, fordi jeg tror, det er en usund måde at lave politik på i et demokrati. I valgkampen har jeg udelukkende gjort rede for, hvad jeg ville arbejde for, hvis jeg blev overborgmester eller mit parti fik tilstrækkelig med indflydelse,” siger hun.

[Interviewer:] Men [...] undersøgte du ikke det realistiske i projektet, inden du gik ud til vælgerne med det? 
”Jo, det gjorde jeg og jeg fastholder, at det stadig kan lade sig gøre - bare ikke på fem år. Jeg kan bare sige, at hver eneste gang, vi støder på en hindring og får brug for hjælp, så er der ingen hjælp at hente. Vi kan ikke som i London stille krav til bygherrerne om, at en vis procentdel af byggeriet skal være billige boliger, og vi kan ikke sælge jord til under markedsprisen. Det er drønærgerligt, for det er altså tvingende nødvendigt, at velfærdssamfundets kernemedarbejdere også har mulighed for at bo i København [...] Men jeg er da helt bevidst om, at den næste valgkamp i nogen grad kommer til at indeholde angreb på min person pga. de billige boliger, men jeg kan kun sige, at vi er i gang med et langt sejt træk, og boligerne skal nok komme - det lover jeg.”

[...]

Som det fremgår, forsøger Ritt Bjerregaard at kaste beskyldningen om løftebrud fra sig på forskellig vis, dels gennem strategien 'at føre krigen over i fjendens lejr' med ordene om regeringens manglende hjælpsomhed og dels ved at benægte at hun skulle have givet et valgløfte. I første omgang giver hun nægtelsen udseende af blot at være en modifikation af løftet, så det kun skulle vedrøre tidshorisonten: Hun fastholder den konstaterende sproghandling at planen om de billige boliger er realisabel, men indrømmer at den ikke kan gennemføres på fem år. For en isoleret betragtning lægges der med udsagnet om at hun aldrig har lovet at boligerne ville stå klar efter fem år, op til at anklagen om løftebrud bygger på en for bogstavelig udlægning af løftet: selvfølgelig kunne man ikke forvente at alle boligerne kunne opføres på fem år. Men denne velvillige udlægning holder ikke i konteksten. Den modsiges i fortsættelsen om at hun er en stærk modstander af kontraktpolitik, og at hun i valgkampen udelukkende har gjort rede for hvad hun ville arbejde for. Hun bencegter altså her i anden omgang hele løftet, ikke bare den ene del om de fem år, men overhovedet at have udstedt et løfte. Absurd nok, slutter afsnittet alligevel med et fornyet løfte: boligerne skal nok komme - det lover hun! (Men bemærk - i lyset af den senere udvikling - at hun nu undlader at sige noget om prisen.)

Gennem krumspringene med sproghandlinger toner en aparte argumentation frem. Ritt Bjerregaard synes at gøre sig til talsmand for at en ytring der er formuleret som et løfte i en valgkamp (på det lokutionære niveau), ikke skal tælle som et rigtigt løfte (på det illokutionære niveau). I samme retning må man forstå journalistens indledende referat om at Ritt Bjerregaard understreger at hun aldrig har lovet at opføre de billige boliger på fem år, kun at hun har lovet at ville arbejde for det. Men denne sondring (at et valgløfte ikke skulle være et løfte), overstiger - som journalisten indskyder - de flestes forstand; den almindelige sprogbruger vil svare at et løfte er et løfte. Og som det fremgik af tekst 1, passer det ikke at Ritt Bjerregaard kun lovede at arbejde for planen med de billige boliger. Hun kunne måske anføre at det var hvad hun egentlig mente dengang, men det var ikke det hun sagde. ${ }^{10}$ Hun

\footnotetext{
${ }^{10}$ I overensstemmelse med the intentional fallacy anlægger jeg her det princip, som også gøres gældende i den pragma-dialektiske argumentationsteori, at retor er forpligtet på den ytrede sproghandling, og at intentionen for så vidt er irrelevant (Eemeren et al. 1996, s. 276-277). Jf. også Searle 1969, s. 62.
} 
lovede under valgkampen at udføre planen, og ved at benægte løftet nu gør hun sig skyldig i lodret løgn.

\section{Diskussion og vurdering}

Analyserne ovenfor påpeger at der i teksterne foreligger eksempler på snyd med talehandlinger mht. selve udførelsen af de sproghandlinger som omgærder sagen om de billige boliger. Men hvilke brud på legitim sproghandlen er der nærmere beset tale om? Hvori består problemet nærmere? Er bruddene af en sådan art at det berettiger til at tale om uredelig argumentation? Og hvor graverende er de i så fald ud fra et normativt retoriksyn? For at indkredse disse spørgsmål følger her iagttagelser mht. de såkaldte vellykkethedsbetingelser ('felicity conditions'), dvs. de kriterier som ifølge talehandlingsteorien knytter sig til udførelsen af en sproghandling, og som sikrer at den er vel udført ('happy'). Som danske betegnelser for vellykkethedsbetingelserne beskrevet af Austin (1975, s. 14ff.) anvendes her kategorierne: forberedelsesbetingelser, oprigtighedsbetingelser og de essentielle betingelser (Husted 1982, s. 242-244).

For at tage det sidste først må det understreges at forpligtelsen til at overholde et løfte sidenhen ikke kan håndhæves ubetinget, men må forstås ud fra devisen 'alt andet lige'. Der findes jo situationer hvor vi accepterer løftebrud. Vi anerkender fx skilsmisser og dermed brud på ægteskabsløftet, og heller ikke i politisk sammenhæng kan det afvises at det kan være fornuftigt at fravige et løfte. Det var jo netop den tvetydige pointe ved Krags topos for politiske løfter: På den ene side udtrykker talemåden (Man har et standpunkt til man tager et nyt) i en nøddeskal den kyniske pragmatikers holdningsskifte ved indgåelse af politiske kompromiser, men på den anden side - og ved nærmere eftertanke - formulerer den det absurde $\mathrm{i}$ at nægte politikeren retten til at skifte mening. Et løftebrud er selvfølgelig undskyldeligt ved uforudsigelige og væsentlige ændringer i omverden (jf. fx Jørgensen 2009). Det må også kunne være det hvis politikeren kommer på bedre tanker ved at lade sig overbevise af det stærkere argument. Sådanne formildende omstændigheder er der imidlertid ikke basis for at anføre for casen her. Det forholder sig ikke sådan at løftet brydes fordi Ritt Bjerregaard har ændret opfattelse i spørgsmålet om det ønskelige i at få opført de billige boliger, og nok er det de ydre omstændigheder der tvinger hende til ikke at opfylde løftet, men der er næppe heller tale om væsentlige ændringer og nye vanskeligheder som ikke kunne forudses da løftet blev afgivet. Det leder frem til de to andre vellykkethedsbetingelser.

Når det drejer sig om brudte valgløfter, er det typisk oprigtighedsbetingelserne som opmærksomheden samler sig om, fordi de som regel skaber mistanke om at løftet blot var politikerens bedrageriske forsøg for at få borgernes stemmer. Standard-eksemplet i den nyere danske debat er Poul Nyrup Rasmussens valgløfte fra folketingsvalget 1998 i den såkaldte efterlønssag (jf. Jørgensen 2007). Som jeg tolker teksterne og forløbet, mener jeg ikke at Ritt Bjerregaard kan beskyldes for at have afgivet et valgløfte som hun ikke ærligt og redeligt ønskede at overholde efter valget. En mere nærliggende forklaring er at det var et forhastet løfte, dvs. et løfte hun ikke havde sikret sig at være i stand til at overholde. 
Hermed er vi tilbage ved den første af vellykkethedsbetingelserne. Som de senere begivenheder vidnede om, og som min tolkning af tekst 2 peger på, havde Ritt Bjerregaard ikke gjort sit politiske forarbejde tilstrækkeligt grundigt da hun gav løftet, og det var derfor hun ikke kunne holde det siden. Denne måde at snyde med sproghandlingen på vedrører forberedelsesbetingelserne, eftersom spørgsmålet er om Ritt Bjerregaard havde forudsætningerne for at udstede et løfte. Problemet i denne henseende er dog ikke om personen er den rette, eller omstændighederne rigtige, til udførelsen af den pågældende talehandling (regel A.2 hos Austin 1975, s. 15). Brud mht. disse krav sætter ifølge Austin talehandlingen ud af kraft - hans betegnelse er at talehandlingen er 'void', hvorved talehandlingen er en 'misfire' (en fuser), dvs. at den ikke er udført på en sådan måde at sproghandlingen kan siges at være effektueret (Ibid. s. 16-17, 25ff.). Denne slags brud er der ikke tale om her; som opstillet kandidat i en valgkamp er Ritt Bjerregaard i en position der sætter hende i stand til at udstede valgløfter. Det egentlige problem ved argumentationen i tekst 1 er den sikkerhed hvormed hun påstår det propositionelle indhold af løftet: at planen for de billige boliger er realisabel. Snyderiet med sproghandlingen angår med andre ord ikke retors oprigtige intentioner, men den ekspertise hun foregiver at sidde inde med.

Dette brud mht. forberedelsesbetingelserne er tilsvarende i strid med kravet om redelighed. Ud fra kriterierne herfor er løftet uredeligt fordi Ritt Bjerregaard - i en kommunikationssituation med et udpræget asymmetrisk kommunikationsforhold - ved at foregive en ekspertise der ikke er dækning for, misbruger sit privilegium som afsender til at bringe modtagerne i en vildfarelse (Jørgensen \& Onsberg 2008, s. 110-111, svensk overs., s. 105-106). I situationen er borgerne i København i deres gode ret til at forvente at Ritt Bjerregaard som kandidat til borgmesterposten på forhånd har sat sig grundigt ind i de lovgivningsmæssige, retlige og byggetekniske regler og de politiske forhindringer der måtte opstå, for helt at affærdige dem. I bestræbelsen på at anlægge graduerede og nuancerede vurderinger kan man måske argumentere for at det ikke er så alvorlig en overtrædelse endda at udtale sig så skråsikkert på et for løst grundlag, fordi Ritt Bjerregaard nok selv troede at vanskelighederne ved planen kunne løses. Hvis hun var i god tro, kan man ikke kalde argumentationen direkte uredelig, hvilket kræver et vist moment af bedragerisk hensigt. I så fald er undskyldningen for det forhastede løfte uvidenhed, et spørgsmål som typisk befinder sig i gråzonen mellem det redelige og uredelige, og som det som regel er svært for kritikeren at tage stilling til fordi man ikke har dokumentation for at kunne udtale sig om det. (jf. Jørgensen 2000, s. 40 note 28, Due 2005). Har Ritt Bjerregaard fået misvisende informationer af dem hun har rådført sig med? Har hun opsøgt uvildige eksperter eller kun dem hun regnede med at få bekræftet planens gennemførlighed hos? Har hun med vilje afholdt sig fra at få fyldestgørende information for ikke at kunne beskyldes for at tale mod bedrevidende? Det sidste er klart uredeligt, men vil højst kunne anføres som en hypotetisk betingelse for kritikerens vurderende stillingtagen. Uanset hvilke formildende eller skærpende omstændigheder man kan tænke sig, mener jeg dog at kritikeren kan gøre gældende at Ritt Bjerregaard i det mindste burde have tilkendegivet at planen var forbundet med visse vanskeligheder. Og havde hun gjort det, ville argumentationen have været mere redelig. 
Mens det altså kan diskuteres hvor uredeligt der argumenteres i form af fortielse i tekst 1, er det Ritt Bjerregaards benægtelse i tekst 2 af det tidligere løfte der udgør det store, alvorlige redelighedsproblem i sagen om de billige boliger. At bestride at hun i valgkampen lovede at bygge 5.000 boliger for 5.000 kr. på fem år, er en direkte løgn og dermed uredeligt og tillige et eksempel på den grove form for snyd med sproghandlinger som Austin kalder 'abusive speech acts' (Austin 1975, s. 16). Som påvist ovenfor, er benægtelsen i direkte modstrid med det løfte, som Ritt Bjerregaard med egne ord havde bundet sig til og derved påtaget sig forpligtelsen til at opfylde, ikke bare at arbejde for.

Hele sagen kan anskues som et eksempel der illustrerer hvordan jagten på det smarte, fængende slogan kan blive en fælde for politikeren selv. At en erfaren politiker som Ritt Bjerregaard får afgivet et valgløfte som ender som en persuasiv boomerang, kan netop tyde på at hun og hendes kampagnerådgivere er blevet forblændede af den flotte stilistiske talmagi med de 5.000 boliger til 5.000 kr. på fem år. I denne udlægning understreger sagen faren ved overfladisk strategisk kommunikationstænkning hvor man går efter persuasiv sejr på kort sigt med midler der er underminerende for etos på langt sigt.

I tilbageblik kan vi konkludere at det første løfte var uklogt, og at Ritt Bjerregaard skulle have formuleret sig anderledes end hun gjorde. Men at benægte løftet sidenhen forekommer at være en så eklatant retorisk brøler at man uvilkårligt må spørge sig selv hvorfor i alverden hun gjorde det? Svaret kan være at alternativet ville involvere en vis indrømmelse mht. politisk inkompetence. Ritt Bjerregaard kunne så have sagt noget i retning af: Jeg beklager at jeg nu må se i øjnene at jeg ikke er i stand til at holde mit valgløfte. I bagklogskabens klare lys indser jeg at jeg ikke skulle have lovet sådan som jeg gjorde. Jeg var dengang overbevist om at planen var realistisk, men jeg undervurderede de vanskeligheder den indebar, og den modstand mine politiske modstandere har mødt projektet med.

Uanset hvordan Ritt Bjerregaard havde grebet tilbagetoget an, ville hendes etos lide skade, og havde hun fulgt den skitserede forsvarsstrategi ville den have forringet hendes etos mht. kompetence-dimensionen (McCroskey 1997). Men skaden for hendes troværdighed og oprigtighed i dimensionen vedrørende personlighedstræk som følge af den indlysende usande benægtelse af løftet må antages at være det mindre onde af de to. I lyset af Ritt Bjerregaards etos som skitseret indledningsvis kunne en tilkendegivelse af egen fejlbarlighed endda have haft den positive effekt at Ritt Bjerregaard kom til at fremstå som mere menneskelig end det offentlige publikum har været tilbøjelig til at betragte hende.

\section{Casestudiets forskningsperspektiver}

Med casestudiet har jeg plæderet for at retorisk kritik kan drage nytte af sproghandlingsteori og fremlagt et eksempel på hvordan det kan gøres. Som det fremgik indledningsvis, har formålet med casestudiet tillige været at tegne konturerne af et forskningsområde med sigte på politisk debatadfærd som involverer snyd med sproghandlinger. Jeg vil afslutningsvis antyde hvordan man vil kunne gå videre med et sådant projekt.

Det må understreges at sprogbrugere altid har brudt den slags regler for legitim sproghandling som er belyst i sagen om de billige boliger. Når jeg peger på snyd med 
sproghandlinger som et emnefelt det er værd for retorikere og andre der beskæftiger sig med sagprosa, at ofre opmærksomhed på, sker det ud fra et indtryk af at det udgør et stigende problem i den danske politiske debat. ${ }^{11}$ Den oplagte skadevirkning af snyd med sproghandlinger er den undergravende betydning som adfærd af denne art har for en konstruktiv deliberativ debat ved at puste til den almindelige mistillid til politikere og bekræfte borgere i det håbløse $\mathrm{i}$ at engagere sig i den offentlige politiske argumentation. Som altid ved undersøgelser motiveret af bekymring over en bestemt kommunikationsadfærd skal man naturligvis vogte sig vel for toposen om sædernes forfald fra fortidens gyldne tilstande, og spørgsmålet om hvorvidt politikere generelt er blevet mere tilbøjelige til at snyde med sproghandlinger nu end tidligere, er for mig at se ikke det væsentlige. Hvorom alting er, står det fast at løfter og undskyldninger gennem de senere år er kommet til at spille en stor rolle i den politiske debat i Danmark, og det er specielt studier af den debatadfærd der omgiver disse sproghandlinger, jeg i første række sigter til.

Er den intensive fokusering på løfter og løftebrud fx et særligt dansk fænomen, eller ser man den samme tendens i de andre nordiske lande? I hvor høj grad er valgløfter fremmende for en demokratisk debat? Hvor går grænsen mellem valgløfter og partiers udmeldinger om de politiske løsninger de går ind for i valgkampen? Hvornår kan man med rette beskylde politikere for løftebrud eller afkræve dem en undskyldning? Hvilke slags brud i forbindelse med disse sproghandlinger er betegnende for den politiske debat, og hvilken betydning har de for indfrielsen af et deliberativt debatideal? Hvornår er det legitimt at skifte mening? Består snyden egentlig snarere i at politiske modstandere bruger anklager om løftebrud og krav om undskyldninger som angrebsstrategier i eristisk øjemed? Hvad er mediernes rolle i denne forbindelse? Er de gyldne løfter fremprovokeret af journalisters forsøg på at presse politikerne til at love dette og hint? Og er løfter overhovedet svar på vælgernes behov og deres mere eller mindre rimelige krav om at kunne holde politikerne fast på den politik partiet gik til valg på? Det er den slags spørgsmål casestudiet i denne artikel lægger op til, og som retoriske kritikker af enkeltsager og andre studier i snyd med sproghandlinger kunne bidrage til at besvare.

\section{Litteratur}

Andersen, J. E. (1989). Sproghandlinger - på dansk. København: Dansklærerforeningen

Aristoteles. (1983). Retorik. Oversat af Hastrup, T. København: Museum Tusculanums Forlag.

Austin, J. L. (1975) [1962]. How to Do Things with Words. 2. udgave. Oxford: Oxford University Press.

Bitzer, L. F. (1968). The Rhetorical Situation. Philosophy and Rhetoric, 1, 1-14. Reprint Philosophy and Rhetoric, Supplementary Issue 1992, 1-14.

Bjerregaard, R. (2005). Kampen om København: København må ikke blive en velhaverghetto. Information d. 27. oktober, s. 22. Net-udgave hentet 24.11.2011, fra http://www.information.dk/114350.

\footnotetext{
${ }^{11}$ Efter præsentationen af casen for det internationale forum på argumentationskonferencen i 2010 tilkendegav adskillige tilhørere at de sad med den samme fornemmelse af et tiltagende problem i deres hjemlige debat.
} 
Davidsen-Nielsen, H. (2009a). Vælgerne spår Frank J. større succes end Ritt B. Politiken d. 26. oktober, s. 3. Davidsen-Nielsen, H. (2009b). Thi kendes for Ritt. Politiken d. 20. december, PS s. 3.

Due, A. (2005). Det var ikke med vilje. Om afsenderintention som parameter i normativ retorik. Rhetorica Scandinavica, 34, 17-34.

Eemeren, F. H. van, Grootendorst, R., \& Henkemans, F. S. (Red.). (1996). Fundamentals of Argumentation Theory. A Handbook of Historical Backgrounds and Contemporary Developments. Mahwah, New Jersey: Lawrence Erlbaum Associates.

Gallup (2007). Ritt Bjerregaards billige boliger (juli 2007). Ugens Gallup nr. 23.

Hansen, E., \& Heltoft, L. (2011). Grammatik over det Danske Sprog. Bind I. København: Det Danske Sprog- og Litteraturselskab.

Henriksen, C. (Red.). (2001). Can you reach the salt? Pragmatikkens klassiske tekster. Frederiksberg: Roskilde Universitetsforlag.

Husted, J. (1982). Austin og Searle: Talehandlinger. I Lübke, P. (Red.). Vor tids filosofi. Videnskab og sprog (s. 236-249). København: Politikens Forlag.

Jens Otto Krag. Hentet 14. november 2011, fra http://da.wikipedia.org/wiki/Jens_Otto_Krag

Jørgensen, C. (2000). Hvem bestemmer hvad der er god retorik? Vurderingsinstanser i normativ retorik. Rhetorica Scandinavica, 15, 34-48.

Jørgensen, C. (2007). The Relevance of Intention in Argument Evaluation. Argumentation, 21, 165-174.

Jørgensen, C. (2009). Retorik som handling i Orla Lehmanns Ridehustale. I Therkelsen, R., \& Jensen, E. S. (Red.). Dramatikken i Grammatikken. Festskrift til Lars Heltoft (s. 203-217). Roskilde: Institut for Kultur og Identitet, Roskilde Universitet.

Jørgensen, C. (2011). Fudging Speech Acts in Political Argumentation. I Eemeren, F. H. van, Garssen, B., Godden, D., \& Mitchell, G. (Red.), Proceedings of the $7^{\text {th }}$ Conference of the International Society for the Study of Argumentation (s. 906-913). Amsterdam: Rozenberg/Sic Sat (cd-rom).

Jørgensen, C., \& Kock, C. (2009). Retoriske funktioner og handlinger. I Jørgensen, C. \& Villadsen, L. (Red.). Retorik. Teori og Praksis (s. 159-175). Frederiksberg: Samfundslitteratur.

Jørgensen, C., \& Onsberg, M. (2008). Praktisk argumentation (3. udgave). København: Nyt Teknisk Forlag. (Svensk oversættelse og bearbejdning ved Vigsö. O. (2008). Praktisk argumentation. Grundbok $i$ retorisk argumentation. Åstorp: Retorikförlaget.)

Kjær, C. \& Jessen, B. (2007). Billige boliger var det store valgtema. Berlingske Tidende d. 11. juli, Indland s. 4-5.

McCroskey, J. C. (1997). Ethos: A Dominant Factor in Rhetorical Communication. An Introduction to Rhetorical Communication (7. udgave, kap. 5, s. 87-107). Boston: Allyn and Bacon.

Nielsen, J., \& Knudsen, J. (2008). Ritt B. opgiver husleje på 5.000 kr. Politiken d. 9. december, s. 5.

Possing, B. (2003): Ritt Bjerregaard. I Dansk kvindebiografisk leksikon. Hentet 14. november 2011, fra http://www.kvinfo.dk/side/597/bio/149/

Qvortrup, H. (2007). Ritts smarte træk. Berlingske Tidende d. 16. juli, s. 11.

Searle, J. R. (1969). Speech Acts: An Essay in the Philosophy of Language. London: Cambridge University Press.

Ritt Bjerregaard. Hentet 14. november 2011, fra http://da.wikipedia.org/wiki/Ritt_Bjerregaard

Villadsen, L. S. (2008). Speaking on Behalf of Others: Rhetorical Agency and Epideictic Functions of Official Apologies. Rhetoric Society Quarterly, 38, 25-45.

Walton, D. (1995). A Pragmatic Theory of Fallacy. Tuscaloosa: The University of Alabama Press.

Weiss, J. (2007). Interview: Jeg har aldrig lovet 5.000 billige boliger på fem år. Berlingske Tidende d. 10. juli, 1. sektion s. 8-9.

Wille, E. W. (2007). Fra tegn til tekst. En indføring i teorier om sproglig kommunikation. Frederiksberg: Samfundslitteratur. 